Lambovska, M., Rajnoha, R., Dobrovic, J. (2019). From Quality to Quantity and Vice Versa: How to Evaluate Performance in the Budgetary Control Process. Journal of Competitiveness, 11(1), 53-69. https:// doi.org/10.7441/joc.2019.01.04

\title{
FROM QUALITY TO QUANTITY AND VICE VERSA: HOW TO EVALUATE PERFORMANCE IN THE BUDGETARY CONTROL PROCESS
}

\section{- Maya Lambovska, Rastislav Rajnoha, Jan Dobrovic}

\begin{abstract}
According to modern management theory, the performance evaluation based entirely on objective indicators within an organization is not considered to be an effective tool. The research objective of this paper is to suggest a contemporary model for evaluation in the budgetary control process of the organization. The model is based on a modern evaluation approach and a complex toolkit of management science and mathematical theories of fuzzy sets and fuzzy logic. In this model, subjective evaluations of the responsibility centres' achievement and performance in budgetary control are generated by fuzzy techniques based on a combination of quantitative and qualitative indicators. The model also allows for an immediate transformation of quantitative into qualitative evaluations and vice versa both in fuzzy and crisp types. The proposed model is an appropriate tool for the subjective performance evaluation of objective results from the organization's budgetary control process under uncertainty. This model was tested in a Bulgarian enterprise for unique wood furniture manufacturing in July 2018 and was applied to five cost centres, with the results demonstrating its applicability. According to our study, the model provides a modern solution to a management problem that is unresolved in the scientific literature and is important to the budgetary management practice of organizations. We believe that the further improvement and implementation of the model will contribute to more effective management and thus to the enhancing competitiveness of the organization.
\end{abstract}

Keywords: budgetary control, performance evaluation, fu₹₹y logic, competitiveness, responsibility accounting JEL Classification: M00, M40, C51, D81, L29

Received: September, 2018

1st Revision: February, 2019

Accepted: February, 2019

\section{INTRODUCTION}

According to modern management theory, the performance evaluation based entirely on objective indicators within an organization is not considered to be an effective tool. (Hope \& Fraser, 2007; Micheli \& Luca, 2014). The application of this management concept implies the need to introduce evaluation models combining both objective (quantitative) and subjective (qualitative) indicators along with tools to better reflect the opinions, influence, and contributions of people 
within the organization (Afonina, 2015; Tuček, 2015). The evaluative problem is particularly complex to solve in terms of management processes employing mainly financial indicators such as the budgetary control of the organization as part of its budgetary management (Lucey, 2009). The application of traditional budgetary management techniques as a key element of management control system is not recommended or even rejected by advocates of this concept (Hope \& Fraser, 2007; Otley 2016). However, there is evidence of a widespread use of budgetary management in the practice of a number of organizations (Otley \& Pollanen, 2000; Dunk, 2011).

Taking into account the necessity of updating evaluation models and tools, we reviewed the scientific literature in the field of performance and budgetary management. Our study was conducted using a combination of the keywords "fuzzy", "evaluation/assessment", "budget control", "responsibility", and "accounting". After locating and analysing 153 titles in Scopus and 9 titles in the Web of Science, we did not find a complete model for the performance evaluation in the budgetary control of the organization. Basic principles and guidelines for developing such a model have been proposed by Lucy (2009) and Drury (2018). As far as managerial practice is concerned, such models undoubtedly exist, but they are not reported in the literature, perhaps because they are owned by consulting companies.

Regarding the applied tools, various principle models for control and evaluation were found in the scientific literature (Kaplan \& Norton 1992; Yiu et al., 2005; Bojadziev \& Bojadziev, 2007; Sousa et al., 2015). As a result of our study in the scientific networks on fuzzy evaluation models in budgetary control, we have drawn four conclusions. Firstly, we did not find a fuzzy model to evaluate performance in the organization's budgetary control process. Secondly, two papers present fuzzy models and are relatively close to our topic according to the keywords used. The first model (Liu, 2015) uses a combination of fuzzy relations and fuzzy logic, and the second one (Moradi et al., 2017) fuzzy logic and interval-valued triangular fuzzy numbers. Thirdly, in instrumental terms, both models are very complex to put into practice. Fourthly, the subject of both models is far from the essence of this study. In methodological terms, the evaluation model proposed by us is based on the Bojadzievs' fuzzy control model (2007). In our opinion, this model presents an opportunity to meet the requirements of the above-mentioned management concept to a great extent. However, the model is too general and refers to control as a whole. Thus, it does not reflect the specificity of the budgetary control within the organization.

In this context, we propose an evaluation model as an attempt to overcome conceptual and methodological gaps in the organization's budgetary control. In the model, the quantitative results achieved in the budgetary control are subjectively evaluated in the context of the qualitative indicators by fuzzy tools. On this basis, we offer new concepts of achievement and performance of group entities in the organization's budgetary control under uncertainty. In our opinion, the model contributes to enhancing the motivation of participants in budgetary control by linking budgetary control to human resources management (Gabčanová, 2013; Todorova \& Marinova, 2018), and thus increasing effectiveness of the organization's budgetary management (Katsamunska, 2016). As a long-term effect (Tododrova, 2012), we believe that the model will contribute to enhancing competitiveness of the organization. 


\section{THEORETICAL BACKGROUND}

In conceptual terms, the evaluation model proposed here is based on theories of management accounting, management control, and performance management.

The unequivocal importance of management accounting theory for this research stems from the fact that budgetary control, as part of budgetary management, falls within the preview of management accounting. In this sense, the place, purpose and role of evaluation in budgetary control are determined here in the context of management accounting theory (Otley \& Soin, 2014; Novák \& Popesko, 2014). We also perceive and employ the following definitions of key concepts of budgetary management formulated in the context of this theory:

- Budgetary management - A management process (Lucey, 2009) aimed at achieving the organization's annual goals. It covers two stages: budgetary planning and control;

- Budgetary control - A process in which performance of the organization and its responsibility centres (RCs) are evaluated and analysed for the reporting (actual) period by their budgets as standards for that period (Otley \& Soin, 2014);

- Budget - A plan with a maximum horizon of one year (Drury, 2018);

- Budget committee - A large focus group formed by experts of the organization and reporting to the top executive manager (Nishimura, 2019);

- Responsibility centre (RC) - An activity area in the organization whose manager is responsible for the results of that area for a certain period. Responsibility centres are classified as cost, revenue, profit and investment centres (Zhang, 2014);

- Cost centre - An activity area of the organization whose manager is responsible for the controllable costs of that centre for a certain period (Papazov \& Mihaylova. 2014);

- Budget deviation - A deviation of the actual result from the budget (Lucey, 2009);

- Allowable area of deviation - The area between the tolerance limits;

- Unallowable budget deviation - The area of budget deviations that does not belong to the allowable area of deviation (Lucey, 2009).

The importance of management control theory is mainly related to the application of some basic approaches of that theory to the evaluation model proposed here. Management by objectives and management by exception are the most important ones for the model. The management by objectives approach (Drucker, 1954) is considered here to be the conceptual basis for choosing input indicators (variables) to evaluate responsibility centres. In this model, the evaluations by input variables and the possible states of the scales are based on the management by exception approach (Bitter, 1964). In addition, some elements of the evaluation procedure are determined in terms of control theory (Flamholtz, 1996).

The performance management theory is the theoretical foundation of this evaluation model. Based on its principles and approaches, the output variables are selected, and most activities of the model are developed. The multidimensional evaluation approach is of great significance for this model, according to which results are not the only indicator of evaluation (Gavurová et al., 2017; Williams, 1998). In its context, the definitions of responsibility centre's achievement and 
performance are formulated in the present paper. Some other concepts used in this model are also defined in terms of performance management theory, with concepts of performance measurement and evaluation the most important. These concepts form the basis of all measurement and evaluation activities of the model. More precisely, we have employed Ilgen and Schneider's understanding of these concepts. Ilgen \& Schneider (1991) define performance measurement to be an activity of quantifying performance and performance evaluation to be an activity of attributing an evaluation of either the value or quality of the quantified performance.

\section{RESEARCH OBJECTIVE, METHODOLOGY AND MODEL}

\subsection{Research objective}

The research objective of this paper is to suggest a contemporary model for evaluation in the budgetary control process of the organization. The modern evaluation approach and the complex toolkit of management science and the mathematical theories of fuzzy logic and fuzzy sets employed in the model are considered to be its main features.

\subsection{Methodology}

In methodological terms, this model is based primarily on theories of fuzzy logic and sets.

Fuzzy logic theory provides a methodology for dealing with linguistic (qualitative) variables, facilitates common sense reasoning with imprecise and vague propositions, and serves as a basis for decision analysis and control actions (Bojadziev \& Bojadziev, 2007). The achievement and performance evaluations of the responsibility centres are created in this model by fuzzy logic tools including linguistic variables and logical decision rules. The features of tools used here are described in paragraph 3.3.

Fuzzy sets theory is defined as an analogue of probability theory applied to the processing of information based on subjective, qualitative evaluations under uncertainty (Kaufman \& GilAluja, 1990). In this model, the mathematical description of evaluations and scales development are carried out by fuzzy sets tools; i.e. fuzzy sets, fuzzy numbers (triangular, trapezoidal), fuzzy random influence matrices and expertons. Input evaluations (except for achievement evaluation) are quantified by fuzzy numbers and output evaluations by fuzzy sets. Fuzzy random influence matrices and expertons (Kaufman \& Gil-Aluja, 1988; Kuzmanova, 2012) are used to develop scales of linguistic variables (input, output).

A survey method using a focus group (called the "budget committee") is applied in this model to evaluate responsibility centres and possible parameters of the scales.

\subsection{Description of the model for evaluation in the budgetary control process}

The model proposed here (Fig. 1) reflects our concept of the essence, activities and products of the evaluation procedure, which is the penult element of the organization's budgetary control process. 


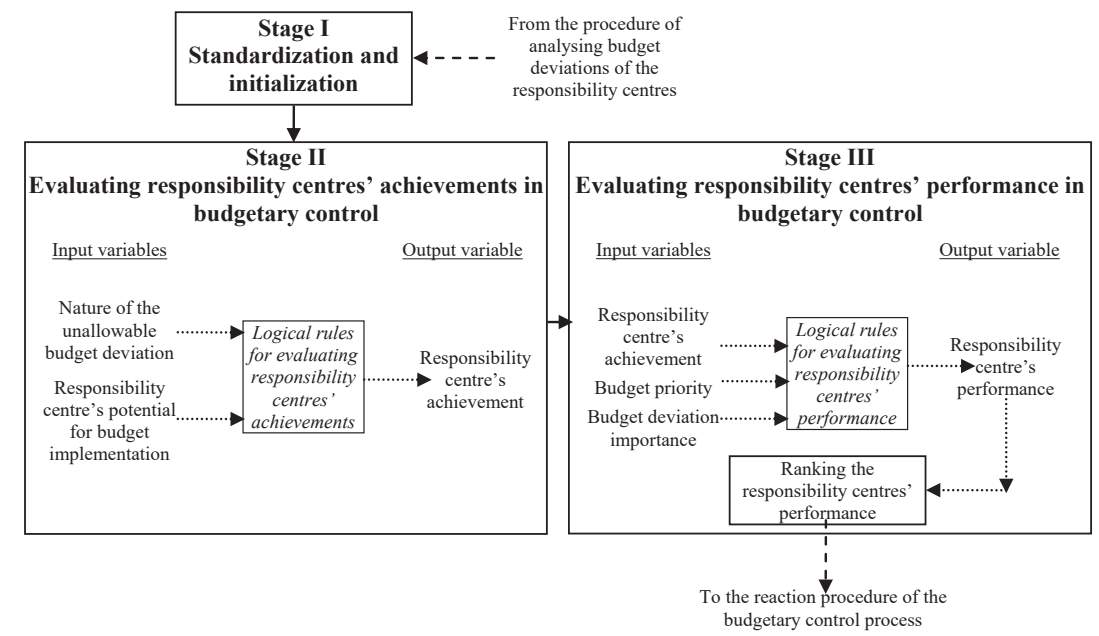

Fig. 1 - Model for evaluation in the organization's budgetary control process. Source: own

The evaluation model has two main features, with the first referring to our understanding of achievement and performance in budgetary control, and the second the approach applied to evaluate the responsibility centres' achievements and performance. In accordance with our approach, the evaluation procedure is performed using fuzzy logic tools in two steps. A transformation of the responsibility centres' evaluations (quantitative and qualitative) of two input variables by fuzzy logical rules is done in the first step, generating as a result qualitative and fuzzy quantitative evaluations of the responsibility centres' achievements in budgetary control. In this context, the achievement evaluation represents the subjective view of the organization's budget committee regarding the responsibility centre's result (unallowable budget deviation) in terms of the centre's potential for budget implementation. In the second step, the achievement evaluations along with the subjective evaluations by two other input variables are transformed into output evaluations of the responsibility centres' performance. The conversion is done by other logical rules. Thus, the performance evaluation represents the subjective view of the budget committee on the responsibility centre's achievement in terms of its role in achieving the annual goals of the organization.

We have determined the evaluation of budgetary control as taking place in three stages (Fig. 1):

- Stage I - Standardization and initialization;

- Stage II - Evaluating responsibility centres' achievements in budgetary control;

- Stage III - Evaluating responsibility centres’ performance in budgetary control.

In the first stage of the model, the initial data are standardized and initialization features of the applied tools are identified. The first stage consists of four procedures (Pr).

The initial data standardization covers the first two procedures. As a result of the first procedure (Pr. 1 "Determining the mathematical nature of RCs' unallowable budget deviations"), two types of mathematical descriptions of unallowable budget deviations could be found - fuzzy sets 
and fuzzy numbers. If these deviations are described by fuzzy numbers, we must proceed to the third procedure. Otherwise, the second procedure (Pr. 2 "Description of the unallowable budget deviations with fuzzy numbers") must be implemented, within which fuzzy sets describing the unallowable budget deviations are transformed into symmetric fuzzy triangular numbers with the same area and nature of the deviations - (un)favourable. The procedure ends by representing the fuzzy numbers of unallowable budget deviations in a discrete (crisp) form through their normalized distance by Hamming called "Hamming's number" (Kaufman \& Gil-Aluja, 1990). The procedure is developed by using the triangle area formula, features of fuzzy triangular numbers and formulas for Hamming's numbers (Tab. 1 and Tab. 4).

Initialization of fuzzy logic tools is performed by the budget committee in the third procedure (Pr. 3 "Initializing the tools of the model"). The initialization is referred to determining the nature, number and states of the linguistic variables (input and output) and fuzzy logical rules. These features are defined in this model separately for stage II and stage III.

Three variables (two inputs and one output) are used in the second stage. The two input variables are the nature of the unallowable budget deviation ("deviation nature"), and the RC's potential for budget implementation ("RC's potential"). Both input variable has three possible states. The states of the "deviation nature" variable (Tab. 1) are unfavourable negative (UN), favourable (F), and unfavourable positive (UP) nature, and those of the "RC's potential" variable (Tab. 4) are low $(\mathrm{L})$, medium $(\mathrm{M})$ and high $(\mathrm{H})$ potential. The output variable of the second stage is the RC's achievement in the budgetary control process (called "RC's achievement"). Its states (Fig. 2) are six: very low (VL), low (L), unsatisfactory (US), satisfactory (S), good (G), and very good (VG) potential.

Four variables are used in the third stage. The input variables are RC's achievement, budget priority, and budget deviation importance. The budget priority is evaluated here in the context of the budget package of the organization. Its possible states (Fig. 3) are three: low (L), medium $(\mathrm{M})$ and high $(\mathrm{H})$ priority. The budget deviation importance is a subjective evaluation of the extent to which the deviation threatens either the achievement of organization's annual goals or the coordination of objectives. Its possible states are three (Fig. 4): little (LT), medium (M) and great (GR) importance. The output variable of the third stage is the RC's performance in budgetary control ("RC's performance"). Its possible states are six (Fig. 5): very poor (VP), poor (P), unsatisfactory (US), satisfactory (S), good (G), and very good (VG) performance.

In this model, the fuzzy logical rules used in the second stage (Tab. 2) are 9 and those in the third stage (Tab. 3) are 54. The preconditions of the second stage rules ("if") are formed as an intersection of two sets ("if ... and ...,") and those of the third stage - of three sets ("if ... and ... and ...,"). These sets represent the input variables of the stage. They are described by fuzzy numbers except for the "RC's achievement" input variable of the third stage.

Scales of linguistic variables (input and output) are determined in the fourth procedure (Pr. 4 "Development of scales for the linguistic variables of the model") by the budget committee through survey method. The scales are standards in terms of control theory and are tools for quantifying (measurement) in terms of performance management theory. Here, the scales are 
used to quantify the qualitative evaluations of the possible states of linguistic variables. They are developed in three activities: primary and secondary evaluation, and scale definition. The evaluations of scales are described quantitatively by fuzzy triangular and trapezoidal numbers. Tools of the fuzzy sets theory are used in the fourth procedure, including mathematical operations with confidence intervals, fuzzy expertons and fuzzy random influence matrices.

In the second stage of the model, the RCs' achievements in the budgetary control over the reporting period are evaluated. This stage covers procedures from five to eight. In them, the evaluations of the input variables are quantified by fuzzy numbers and these of the output variable by fuzzy set. Tools used are focus groups, survey method, and fuzzy logic tools.

The RCs' potential for budget implementation is evaluated in the fifth procedure (Pr. 5 "Evaluating the potential of responsibility centres for budget implementation"). The evaluations are generated by a survey among budget committee members and a subsequent average of their evaluations through the tools of fuzzy set theory.

The qualitative evaluations of the "deviation nature" input variable are automatically formed in the sixth procedure (Pr. 6 "Generating qualitative evaluations of the nature of responsibility centres' unallowable budget deviations”) as a result of applying the defuzzified unallowable budget deviations to the scale of that variable.

The other two procedures cover activities of the fuzzy logic application as an evaluation tool. In the seventh procedure (Pr. 7 “Applying logical rules for evaluating the responsibility centres' achievements"), the fuzzy logical rules of the second stage are applied as follows (Bojadziev \& Bojadziev, 2007): encoding the input variables, developing an induced decision table, determining the active cells of the induced decision table, and defining the active rules for evaluating the RCs' achievements. Encoding an input variable means to match the specific evaluations (called "readings", they are generated in the previous two procedures in the second stage) of that variable with fuzzy membership functions representing the possible states of its scale. The results of encoding are called "fuzzy reading inputs" (Mamdani \& Assilian, 1975). The induced decision table is made by replacing the rules in the decision table with the corresponding membership functions of the fuzzy reading inputs (Bojadziev \& Bojadziev, 2007). Active cells of the induced decision table are those with a value other than zero. Active rules for evaluation are located in the active cells of the induced decision table.

Fuzzy evaluations of the RCs' achievements (Fig. 2) are generated in the eighth procedure (Pr. 8 “Generating achievement evaluations of responsibility centres"). They are described by fuzzy sets. The eighth procedure covers two activities (Bojadziev \& Bojadziev, 2007): developing tables of fuzzy decision about the RCs' achievements and determining fuzzy evaluations of the RCs' achievements. The fuzzy decision table is an analogue of the induced decision table which systematizes the outputs resulting from the application of the min function to the fuzzy reading inputs of the active rules. Fuzzy evaluations of the RC's achievement are generated by aggregating all the non-zero results described in the fuzzy decision table through the max function (Bojadziev \& Bojadziev, 2007). 
In the third stage of the model, the RCs' performance in the budgetary control over the reporting period is evaluated. Ranking of RCs' performance is done as well. The third stage covers procedures from nine to fourteen. Tools used in it are the same as in the second one.

The ninth and tenth procedures (Pr. 9 "Evaluating the budget priority", Pr. 10 "Evaluating the budget deviation importance") are done by analogy to the fifth procedure. As a result, the evaluations of the "budget priority" (Fig. 3) and "budget deviation importance" (Fig. 4) are generated. They are described by fuzzy numbers and their Hamming's numbers.

The eleventh procedure (Pr. 11 “Applying logical rules for evaluating the responsibility centres' performance") is done by analogy to the seventh procedure of the model. There are three differences between these procedures. Firstly, the input variables of the third stage are three. Secondly, readings of the "RC's achievement" input variable are described by fuzzy sets. Thirdly, the fuzzy reading inputs of this variable are determined by the max-min function according to both the approach of Mamdani \& Assilian (1975) to define the preconditions of logical rules and the aggregation principle of fuzzy results (Bojadziev \& Bojadziev, 2007).

The twelfth procedure (Pr. 12 "Generating performance evaluations of responsibility centres") is done by analogy to the eighth procedure. In it, the evaluations of the "RC's performance" (Fig. 5) output variable are generated. They are described by fuzzy sets.

The fuzzy evaluations of RCs' performance are defuzzified (Fig. 5) in the thirteenth procedure (Pr. 13 "Defuzzification of the evaluations of responsibility centres' performance"). In the scientific literature (Bojadziev \& Bojadziev, 2007), defuzzification is defined as a presentation of a fuzzy set/ number discretely by a single value that adequately represents the membership function of that fuzzy set/ number.

In the fourteenth procedure (Pr. 14 "Ranking the results of the responsibility centres' performance"), the RCs' performance is ranked in decreasing order (Tab. 5).

\section{RESULTS}

The evaluation model proposed in this paper was tested in July 2018 at Twins Design Ltd. (TD). It is a Bulgarian enterprise for unique wooden furniture manufacturing. The evaluation model was applied to five cost centres (called here "centres") of TD. Three centres (1,2, and 3) were workshops and two centres (4 and 5) performed administrative functions.

The main results of testing the model at TD are presented in this paper consistently with the model's procedures. The results published here are not representative of the TD's activity. The scales and quantitative evaluations used herein are dimensionless except for the evaluations in Tab. 1.

The results of Pr. 1 and Pr. 2 (Tab. 1) cover the unallowable budget deviations and allowable areas of budget deviation of TD's centres. They were normalized within the range $[0 ; 1]$. As a result of Pr. 2, the deviations of centres 4 and 5 were converted from fuzzy sets into symmetric fuzzy triangular numbers. 
Tab. 1 - Unallowable budget deviations of the cost centres of Twins Design Ltd. for July 2018. Source: own

\begin{tabular}{|c|c|c|c|c|c|c|c|c|c|c|c|}
\hline \multirow{4}{*}{ 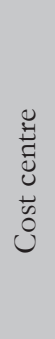 } & \multicolumn{7}{|c|}{ Unallowable budget deviation (BGN) } & \multirow{2}{*}{\multicolumn{4}{|c|}{$\begin{array}{l}\text { Allowable area of de- } \\
\text { viation (BGN) } \\
\text { Possibility }\end{array}$}} \\
\hline & \multirow{3}{*}{ Type } & \multicolumn{4}{|c|}{ Possibility } & \multirow{2}{*}{$\begin{array}{l}\text { Ham- } \\
\text { ming's } \\
\text { number }\end{array}$} & \multirow{3}{*}{$\begin{array}{l}\text { Qualitative } \\
\text { nature of } \\
\text { Ham- } \\
\text { ming's } \\
\text { number }\end{array}$} & & & & \\
\hline & & $\begin{array}{l}a=0 \\
\min \end{array}$ & $\begin{array}{l}\mathrm{a}=1 \\
\min \end{array}$ & $\begin{array}{l}a=1 \\
\max \end{array}$ & $\begin{array}{l}a=0 \\
\max \end{array}$ & & & \multirow{2}{*}{$\begin{array}{l}a=0 \\
\min \end{array}$} & \multirow{2}{*}{$\begin{array}{l}a=1 \\
\min \end{array}$} & \multirow{2}{*}{$\begin{array}{l}a=1 \\
\max \end{array}$} & \multirow{2}{*}{$\begin{array}{l}a=0 \\
\max \end{array}$} \\
\hline & & 1 & 2 & 3 & 4 & $5^{*}$ & & & & & \\
\hline 1 & $\begin{array}{l}\text { Fuzzy } \\
\text { number }\end{array}$ & 0.64 & 0.68 & 0.68 & 0.76 & 0.69 & Favourable & 0.43 & 0.45 & 0.52 & 0.56 \\
\hline 2 & $\begin{array}{l}\text { Fuzzy } \\
\text { number }\end{array}$ & 0.55 & 0.61 & 0.61 & 0.67 & 0.61 & Favourable & 0.45 & 0.47 & 0.53 & 0.55 \\
\hline 3 & $\begin{array}{l}\text { Fuzzy } \\
\text { number }\end{array}$ & 0.75 & 0.81 & 0.81 & 0.95 & 0.83 & $\begin{array}{l}\text { Favourable } \\
\text { - Unfa- } \\
\text { vourable } \\
\text { positive }\end{array}$ & 0.39 & 0.42 & 0.53 & 0.6 \\
\hline \multirow{2}{*}{4} & $\begin{array}{l}\text { Fuzzy } \\
\text { set }\end{array}$ & 0.13 & 0.2 & 0.24 & 0.17 & & \multirow{2}{*}{$\begin{array}{l}\text { Unfavour- } \\
\text { able nega- } \\
\text { tive }\end{array}$} & & & & \\
\hline & $\begin{array}{l}\text { Fuzzy } \\
\text { number }\end{array}$ & 0.07 & 0.12 & 0.12 & 0.17 & 0.12 & & 0.17 & 0.31 & 0.64 & 0.81 \\
\hline \multirow{2}{*}{5} & $\begin{array}{l}\text { Fuzzy } \\
\text { set }\end{array}$ & 0.16 & 0.29 & 0.3 & 0.17 & & \multirow{2}{*}{$\begin{array}{l}\text { Unfavour- } \\
\text { able nega- } \\
\text { tive }\end{array}$} & & & & \\
\hline & $\begin{array}{l}\text { Fuzzy } \\
\text { number }\end{array}$ & 0.15 & 0.16 & 0.16 & 0.17 & 0.16 & & 0.17 & 0.31 & 0.64 & 0.81 \\
\hline
\end{tabular}

$*=[\operatorname{sum}(1: 4)+\operatorname{sum}(2: 3)] / 6$

The results of $\operatorname{Pr} 3$ refer to the features of the fuzzy logic tools used in this study. The features of the linguistic variables were described in paragraph 3.3. The TD's logical rules employed in the second and third stage are shown in Tab. 2 and Tab. 3 respectively. The decision table in Tab. 3 consists of three elements corresponding to the possible states (LT, M, GR) of the "budget deviation importance" input variable. The logical rule number in Tab. 2 and Tab. 3 is shown in brackets. Shaded cells of these tables contain the active rules for this study.

Tab. 2 - Decision table of Twins Design Ltd. for evaluation at stage II. Source: own

\begin{tabular}{|l|l|l|l|l|}
\hline \multirow{2}{*}{$\begin{array}{l}\text { Cost centre's achievement in the budgetary } \\
\text { control process }\end{array}$} & \multicolumn{3}{|l|}{ Nature of the unallowable budget deviation } \\
\cline { 3 - 5 } & UN & F & UP \\
\hline $\begin{array}{l}\text { Cost centre's potential } \\
\text { for budget implementa- } \\
\text { tion }\end{array}$ & L & US (1) & VG (2) & G (3) \\
\cline { 2 - 5 } & M & L (4) & G (5) & S (6) \\
\cline { 2 - 5 } & H & VL (7) & S (8) & US (9) \\
\hline
\end{tabular}


Tab. 3 - Decision table of Twins Design Ltd. for evaluation at stage III. Source: own

\begin{tabular}{|c|c|c|c|c|c|c|c|c|c|c|c|c|c|c|}
\hline \multirow{2}{*}{ BDI* } & \multirow{2}{*}{ LT } & \multicolumn{3}{|c|}{ Budget priority } & \multirow{2}{*}{$\mathrm{BDI}^{*}$} & \multirow{2}{*}{ M } & \multicolumn{3}{|c|}{ Budget priority } & \multirow{2}{*}{ BDI* $^{*}$} & \multirow{2}{*}{ GR } & \multicolumn{3}{|c|}{ Budget priority } \\
\hline & & $\mathrm{L}$ & M & $\mathrm{H}$ & & & $\mathrm{L}$ & M & $\mathrm{H}$ & & & L & M & $\mathrm{H}$ \\
\hline \multirow{6}{*}{ 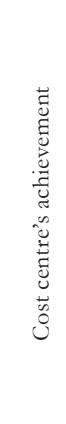 } & VL & $\mathrm{P}(1)$ & $\mathrm{P}(2)$ & $\begin{array}{l}\text { VP } \\
\text { (3) }\end{array}$ & \multirow{6}{*}{ 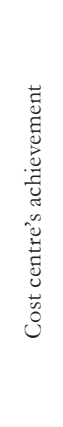 } & $\mathrm{VL}$ & $\begin{array}{l}\text { VP } \\
(19)\end{array}$ & $\begin{array}{l}\text { VP } \\
\text { (20) }\end{array}$ & $\begin{array}{l}\text { VP } \\
(21)\end{array}$ & \multirow{6}{*}{ 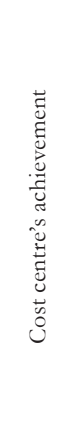 } & VL & $\begin{array}{l}\text { VP } \\
\text { (37) }\end{array}$ & $\begin{array}{l}\text { VP } \\
\text { (38) }\end{array}$ & $\begin{array}{l}\text { VP } \\
\text { (39) }\end{array}$ \\
\hline & L & $\mathrm{P}(4)$ & $\mathrm{P}(5)$ & $\mathrm{P}(6)$ & & $\mathrm{L}$ & $\mathrm{P}(22)$ & $\begin{array}{l}\text { VP } \\
\text { (23) }\end{array}$ & $\begin{array}{l}\text { VP } \\
\text { (24) }\end{array}$ & & L & $\begin{array}{l}\mathrm{P} \\
(40)\end{array}$ & $\begin{array}{l}\text { VP } \\
(41)\end{array}$ & $\begin{array}{l}\text { VP } \\
\text { (42) }\end{array}$ \\
\hline & US & $\begin{array}{l}\text { US } \\
\text { (7) }\end{array}$ & $\begin{array}{l}\text { US } \\
\text { (8) }\end{array}$ & $\begin{array}{l}\text { US } \\
(9)\end{array}$ & & US & $\begin{array}{l}\text { US } \\
\text { (25) }\end{array}$ & $\mathrm{P}(26)$ & $\begin{array}{l}\mathrm{P} \\
(27)\end{array}$ & & US & $\begin{array}{l}\text { P } \\
\text { (43) }\end{array}$ & $\begin{array}{l}\text { P } \\
(44)\end{array}$ & $\begin{array}{l}\text { VP } \\
\text { (45) }\end{array}$ \\
\hline & S & S (10) & S (11) & $S(12)$ & & S & S (28) & $\begin{array}{l}\text { US } \\
\text { (29) }\end{array}$ & $\begin{array}{l}\text { US } \\
\text { (30) }\end{array}$ & & S & $\begin{array}{l}\text { US } \\
(46)\end{array}$ & $\begin{array}{l}\text { US } \\
\text { (47) }\end{array}$ & $\begin{array}{l}\text { US } \\
\text { (48) }\end{array}$ \\
\hline & G & $\begin{array}{l}\text { G } \\
\text { (13) }\end{array}$ & G (14) & $\begin{array}{l}\text { G } \\
\text { (15) }\end{array}$ & & G & $\begin{array}{l}\text { G } \\
\text { (31) }\end{array}$ & $\begin{array}{l}\text { G } \\
(32)\end{array}$ & $\begin{array}{l}\mathrm{S} \\
\text { (33) }\end{array}$ & & G & $\begin{array}{l}\text { G } \\
(49)\end{array}$ & $\begin{array}{l}\mathrm{S} \\
(50)\end{array}$ & $\begin{array}{l}S \\
\text { (51) }\end{array}$ \\
\hline & VG & $\begin{array}{l}\text { G } \\
(16)\end{array}$ & $\begin{array}{l}\text { G } \\
(17)\end{array}$ & $\begin{array}{l}\text { VG } \\
\text { (18) }\end{array}$ & & VG & $\begin{array}{l}\text { G } \\
(34)\end{array}$ & $\begin{array}{l}\text { VG } \\
\text { (35) }\end{array}$ & $\begin{array}{l}\text { VG } \\
\text { (36) }\end{array}$ & & VG & $\begin{array}{l}\text { G } \\
(52)\end{array}$ & $\begin{array}{l}\text { VG } \\
\text { (53) }\end{array}$ & $\begin{array}{l}\text { VG } \\
\text { (54) }\end{array}$ \\
\hline
\end{tabular}

* Budget deviation importance

The results of Pr. 4 are the scales of variables. They are shown as follows: a) Scales of input variables (stage III): "RC's (cost centre's in this context - CC's) achievement" - in Fig. 2, "budget priority" - in Fig. 3, and "budget deviation importance" - in Fig. 4; The scales of input variables used in stage II are not presented here. b) Scales of output variables: "CC's achievement" (stage II) - in Fig. 2, and "CC's performance" (stage III) - in Fig. 5.

The results of Pr. 5 cover the evaluations of the "CC's potential" variable (Tab. 4). They were: low-medium - centres 1, 4, and 5; medium - centre 3; and medium-high - centre 2.

Tab. 4 - Potential for budget implementation of the cost centres of Twins Design Ltd. for July 2018. Source: own

\begin{tabular}{|c|c|c|c|c|c|}
\hline \multirow{4}{*}{ 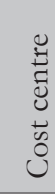 } & \multicolumn{5}{|c|}{ Potential for budget implementation } \\
\hline & \multicolumn{3}{|c|}{ Possibility } & \multirow{2}{*}{ Hamming's number } & \multirow{3}{*}{$\begin{array}{l}\text { Qualitative evaluation } \\
\text { of Hamming's number }\end{array}$} \\
\hline & $\mathrm{a}=0 \mathrm{~min}$ & $\mathrm{a}=1 \mathrm{~min}$ & $a=0 \max$ & & \\
\hline & 1 & 2 & 3 & $4=0.25 \operatorname{sum}(1: 3,2)$ & \\
\hline 1 & 0.04 & 0.26 & 0.47 & 0.26 & Low - Medium \\
\hline 2 & 0.58 & 0.7 & 0.75 & 0.68 & Medium - High \\
\hline 3 & 0.28 & 0.34 & 0.37 & 0.33 & Medium \\
\hline 4 & 0.2 & 0.23 & 0.31 & 0.24 & Low - Medium \\
\hline 5 & 0.23 & 0.28 & 0.34 & 0.28 & Low - Medium \\
\hline
\end{tabular}

The results of Pr. 6 cover the qualitative evaluations of the unallowable budget deviation of TD's centres (Tab. 1). In this study, the unallowable budget deviations were of the following nature: favourable - centres 1 and 2; unfavourable negative - centres 4 and 5; favourable-unfavourable positive - centre 3. According to the results, centre 2 had the best result of Pr. 6 because Hamming's number of its deviation was the smallest favourable one (0.61, Tab. 1). 
The results of Pr. 7 and Pr. 8 consist of the TD centres' evaluations of achievement in budgetary control (p. A1, A2, A3, A4, and A5 in Fig. 2). They are presented in Fig. 2 in a discrete form and were calculated through defuzzification of their fuzzy sets by the centre of area (CA) method (Bojadziev \& Bojadziev, 2007) applied to ten evaluations of each fuzzy set.

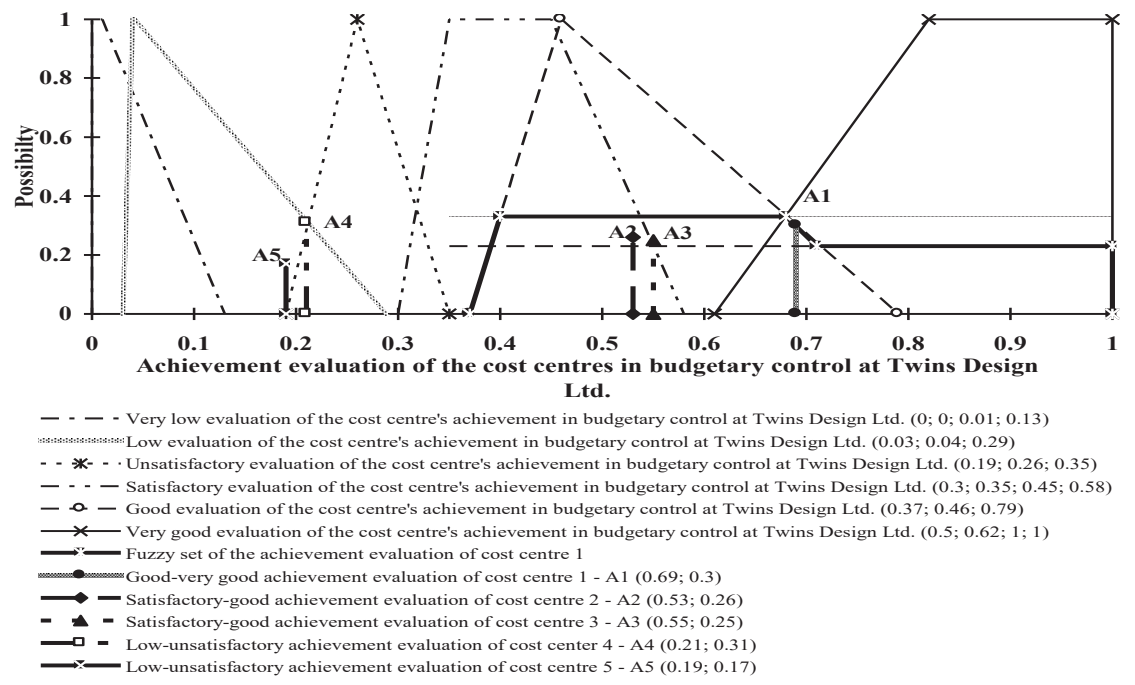

Fig. 2 - Achievements of the cost centres in the budgetary control process of Twins Design Ltd.(7/2018). Source: own

The results of Pr. 9 and Pr. 10 cover the evaluations of budget priority (Fig. 3) and budget deviation importance (Fig. 4) of TD's centres respectively. According to the results, centre 1 had the top priority budget (0.66, medium-high, p. B1 in Fig. 3) and the most important budget deviation (0.62, mediumgreat, p. I1 in Fig. 4). Centre 5 had the most non-priority budget (0.32, low-medium, p. B5 in Fig. 3) and the least important budget deviation (0.31, little-medium, p. I5 in Fig. 4). The discrete values in Fig. 3 and Fig. 4 represent Hamming's numbers of the evaluations described by fuzzy numbers.

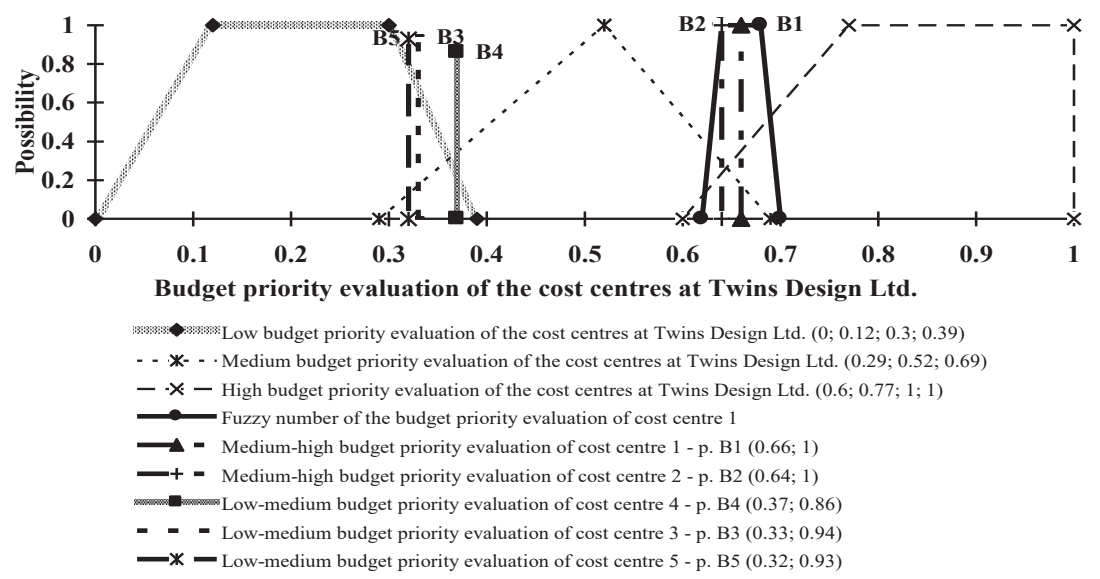

Fig. 3 - Budget priority of the cost centres of Twins Design Ltd. for July 2018. Source: own 


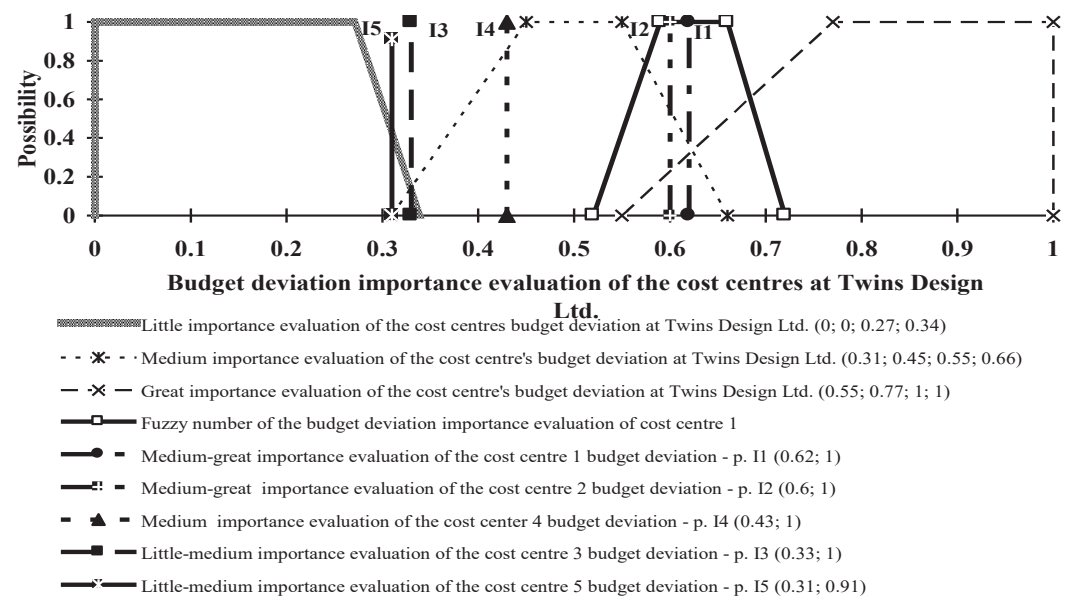

Fig. 4 - Budget deviation importance of the cost centres of Twins Design Ltd. for July 2018. Source: own

The results of $\operatorname{Pr} 11, \operatorname{Pr} 12$, and $\operatorname{Pr} 13$ consist of the performance evaluations of TD's centres (Fig. 5). The defuzzified evaluations of all centres (p. P1, P2, P3, P4, and P5 in Fig. 5) were calculated by the CA method through ten evaluations of each fuzzy set.

The results of Pr 14 (Tab. 5) cover the performance ranking of TD’s centres for July 2018.

Tab. 5 - Performance ranking of the cost centres in the budgetary control process of Twins Design Ltd. for July 2018. Source: own

\begin{tabular}{|l|l|l|l|}
\hline \multirow{2}{*}{ Cost centre } & \multicolumn{2}{|l|}{ Performance evaluations in budgetary control by the CA method } & \multirow{2}{*}{ Rank } \\
\cline { 2 - 4 } & Quantitative & Qualitative & \\
\hline 1 & 0.683 & Good - very good & 1 \\
\hline 2 & 0.4569 & Satisfactory & 3 \\
\hline 3 & 0.4825 & Satisfactory & 2 \\
\hline 4 & 0.2187 & Poor & 5 \\
\hline 5 & 0.2912 & Poor - unsatisfactory & 4 \\
\hline
\end{tabular}




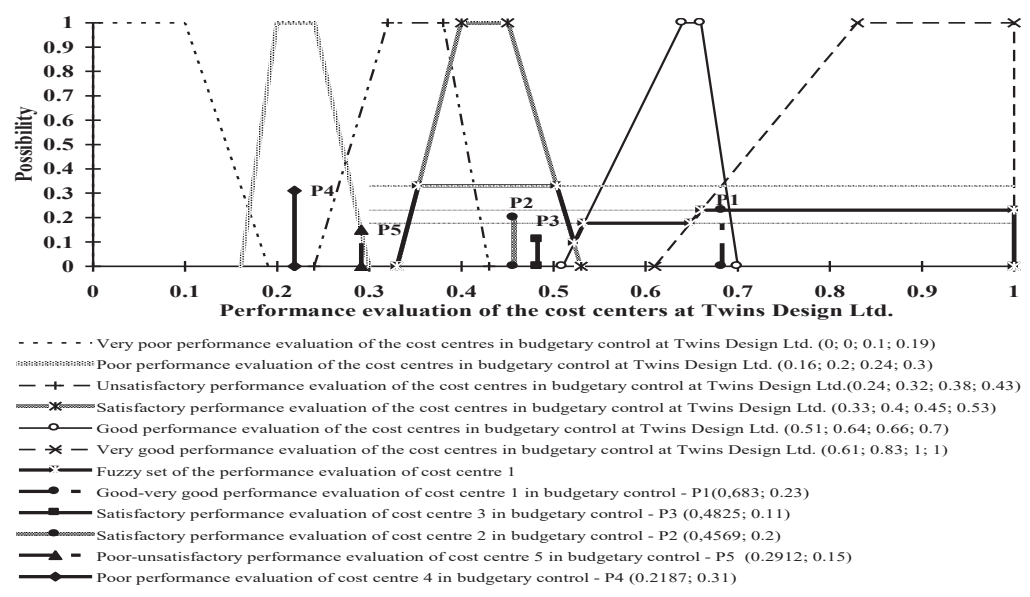

Fig. 5 - Performance of the cost centres in the budgetary control process of Twins Design Ltd. (7/2018). Source: own

\section{DISCUSSION}

The comparative analysis of the cost centres' results in the budgetary control of TD for July 2018 provide the basis for the following findings:

\section{Concerning the cost centres' achievements:}

Centre 1 reached the highest achievement evaluation among TD's centres (p. A1 in Fig. 2) (goodvery good). This was achieved despite the second most favourable result of that centre by "deviation nature" variable (0.69, Tab. 1). In our opinion, the main reason for this highest result is the nature of logical rules 2 and 5 (Tab. 2) applied to the low-medium potential of centre 1 for budget implementation (0.26, Tab. 4).

Close achievement evaluations of centres 2 and 3 were generated (p. A2, p. A3 in Fig. 2). Qualitative evaluations of both centres were the same (satisfactory-good). Yet, the quantitative evaluation of centre 3 (0.55, p. A3 in Fig. 2) was higher than those of centre 2 (0.53, p. A2 in Fig. 2). This result was reached despite the best evaluation of centre 2 by the "deviation nature" variable (0.61, Tab. 1) and the fact that the logical rules applied to evaluate both centres (Tab. 2, centre 2: rules 5 and 8 , centre 3: rules 5 and 6 ) predetermine the same qualitative evaluations. The researchers propose that this better result of centre 2 is due to its higher potential for budget implementation (0.68, medium-high, Tab. 4) compared to centre 3 (0.33, medium, Tab. 4).

Close achievement evaluations of centres 4 and 5 were also generated (p. A4, A5 in Fig. 2). Logical rules 1 and 4 (Tab. 2) were used for their generation. Centres 4 and 5 showed the same qualitative evaluations (low-unsatisfactory) but different quantitative ones - 0.21 and 0.19 respectively. These results are based on the same qualitative evaluations by the variables "deviation nature" (unfavourable negative, Tab. 1) and "CC's potential” (low-medium, Tab. 4) but different quantitative ones. 


\section{Concerning the cost centres' performance:}

Centre 1 was ranked first in the performance ranking of TD's centres (good-very good evaluation, 0.683 , p. P1 in Fig. 5, Tab. 5). The researchers propose that this result is a consequence of both maximal evaluations of centre 1 by input variables (achievement: good-very good, 0.69, p. A1 in Fig. 2; budget priority: medium-high, 0.66, p. B1 in Fig. 3; budget deviation importance: medium-great, 0.62 , p. I1 in Fig. 4) and the logical rules used to evaluate its performance (32, 33, $35,36,50,51,53$, and 54 in Tab. 3).

Centres 2 and 3 achieved close performance results, with their performance evaluated to be satisfactory (p. P2 and P3 in Fig. 5). The quantitative evaluation of centre 3 was higher $(0.4825$, p. P3 in Fig. 5) than that of centre 2 (0.4569, p. P2 in Fig. 5). Based on the quantitative results, centre 3 was ranked second and centre 2 ranked third in the TD's performance ranking (Tab. 5). The researchers propose that the different performance results are due to significant differences between the centres' evaluations by the input variables "budget priority" (Fig. 3, centre 2: 0.64, medium-high, p. B2; centre 3: 0.33, low-medium, p. B3) and "budget deviation importance" (Fig. 4, centre 2: 0.6, medium-great, p. I2; centre 3: 0.33, little-medium, p. I3). Based on these different evaluations, the logical rules applied to evaluate the centres' performance were also different (Tab. 3, centre 2: rules 29, 30, 47, 48; centre 3: rules 10, 11, 28, 29).

Centre 4 achieved the worst performance (poor evaluation, 0.2187, p. P4 in Fig. 5). Thus, its rank was the lowest one - fifth (Tab. 5). This result was achieved although the input evaluations of centre 4 were not the minimal ones (achievement: low-unsatisfactory, 0.21, p. A4 in Fig. 2; budget priority: low-medium, 0.37, p. B4 in Fig. 3; budget deviation importance: medium, 0.43, p. I4 in Fig. 4). The researchers propose that this worst result is based on both logical rules $(22,23,25$, and 26, Tab. 3) applied to evaluate the performance of centre 4 and its fuzzy reading inputs of achievement (p. A4 in Fig. 2).

The performance of centre 5 was ranked fourth (Tab. 5). Its evaluation was poor-unsatisfactory $(0.2912$, p. P5 in Fig. 5), a result reached although the input evaluations of centre 5 were the minimal ones (achievement: low-unsatisfactory, 0.19, p. A5 in Fig. 2; budget priority: lowmedium, 0.32, p. B5 in Fig. 3; budget deviation importance: little-medium, 0.31, p. I5 in Fig. 4). The performance evaluation of centre 5 is based on the logical rules $4,5,7,8,22,23,25$, and 26 (Tab. 3).

The following recommendations should be made to the TD's budget committee:

- The scales for evaluating TD's cost centres by all variables should be refined. The range of the highest possible state (VG, H, GR) of all the scales used in this study was too wide compared to other states (Fig. 2, Fig. 3, Fig.4, and Fig. 5).

- Different scales should be developed to evaluate different types of responsibility centres (revenue, cost, profit, and investment centres) in the budgetary control of TD.

- Scales and logical rules for evaluation should be tailored to the specifics of the reporting period for which the TD's responsibility centres are evaluated.

The following main conclusions from this study could be drawn: 
- The evaluation model proposed here was successfully implemented in the budgetary control process of Twins Design Ltd. in July 2018. As evidence of this, the qualitative and quantitative performance evaluations of TD's cost centres were generated and ranked.

- The model provides an opportunity for the management (budget committee) to evaluate objective results (Fig. 1) from the budgetary control (RCs' unallowable budget deviations, Tab. 1) in terms of subjective criteria (budget priority, budget deviation importance, RCs' potential, Tab. 4, Fig. 3, Fig. 4) describing the RCs' role in achieving the annual goals of the organization. We consider this feature of the model as its main advantage compared to conventional models.

- Furthermore, quantitative evaluations are described by subjective distributions (Tab.1, Tab. 4, Fig. 3 to Fig. 5) consisting of confidence intervals for each possibility $\alpha$ in the range $[0 ; 1]$. Consequently, the model is an appropriate tool for subjective evaluation of the RCs' performance in budgetary control under uncertainty.

- In addition, the model makes it possible to take into account the impact of the organization and its environment on performance in budgetary control. Adaptation to changes could be achieved by adjusting the scales and subjective evaluations.

- Another major advantage of the model is that it allows immediate transformation of quantitative into qualitative evaluations and vice versa both in fuzzy and crisp types.

\section{CONCLUSIONS}

An original model to evaluate performance in the budgetary control process of the organization is proposed in this paper. The model is based on a contemporary evaluation approach and a complex toolkit of management science and mathematical theories of fuzzy logic and fuzzy sets. The practical applicability of the model was demonstrated empirically for a Bulgarian enterprise.

The researchers propose that opportunities for the future improvement of the evaluation model could be found in the following directions: increasing the number of input variables used to evaluate the responsibility centres' achievements and performance in budgetary control, taking into account the views and influence of other stakeholders (external and internal) in determining subjective evaluations of the responsibility centres, elaborating the model and/or connecting it more closely with the reaction procedure of the budgetary control process, linking the model with the human resource management system of the organization. We believe that the implementation and further improvement of the model will contribute to more effective management and thus to enhancing the competitiveness of organizations.

\section{References}

1. Afonina, A. (2015). Strategic Management Tools and Techniques and Organizational Performance: Findings from the Czech Republic. Journal of Competitiveness, 7 (3), 19-36.

2. Bitter, L. (1964). Management by Exception. New York, NY: McGraw-Hill. 
3. Bojadziev, G., \& Bojadziev, M. (2007). Fu₹zy Logic for Business, Finance, and Management (2nd ed.). Singapore: World Scientific publishing. http://dx.doi.org/10.1142/9789812770622_ 0005

4. Drucker, P. (1954). The Practice of Management. New York, NY: Harper \& Bros. https://doi. org/10.1080/05775132.1954.11468040

5. Drury, C. (2018). Management and Cost Accounting (3rd ed.). Boston, MA: Springer. http:// dx.doi.org/10.1007/978-1-4899-6828-9

6. Dunk, A. (2011). Product Innovation, Budgetary Control, and Financial Performance of Firms. The British Accounting Review, 43 (2), 102-111. https://doi.org/10.1016/ j.bar.2011.02.004

7. Flamholtz, E. (1996). Effective Management Control: Theory and Practice. Norwell, MA: Kluwer Academic Publishers. http://dx.doi.org/10.1007/978-1-4613-1359-5

8. Gabčanová, I. (2013). Human Resources Key Performance Indicators. Journal of Competitiveness, 4 (1), 117-128. https://doi.org/10.7441/joc.2012.01.09

9. Gavurová, B., Belás, J., Kočišová, K., \& Klieštik, T. (2017). Comparison of Selected Methods for Performance Evaluation of Czech and Slovak Commercial Banks. Journal of Business Economics and Management, 18 (5), 852-856. http://dx.doi.org/10.3846/16111699.2017 .1371637

10. Hope, J., \& Fraser, R. (2007). Beyond Budgeting Wie sich Manager aus der jäbrlichen Budgetierungsfalle befreien können. In: Boersch C., Elschen R. (eds) Das Summa Summarum des Management. Gabler. https://doi.org/10.1007/978-3-8349-9320-5_30

11. Ilgen, D., \& Schneider, J. (1991). Performance Measurement: A Multidiscipline View. International Review of Industrial and Organizational Psychology, 6, 71-108.

12. Kaplan, R., \& Norton, D. (1992). The Balanced Scorecard: Measures That Drive Performance. Harvard Business Review, 70 (1), 71-79.

13. Katsamunska, P. (2016). Modern Policy of Human Resources Management in Administration and Competency Approach in Training. Strategies for Policy in Science and Education, 24 (4), 362-377.

14. Kaufmann, A., \& Gil-Aluja, J. (1990). Laz Matematicas del Azary de la Incertidumbre. Madrid: Ediciones Graficas Ortega.

15. Kaufmann, A., \& Gil-Aluja, J. (1988). Modelos para la Investigacion de Efectos Olvidados. Vigo: Pugalsa.

16. Kuzmanova, M. (2012). Creation of Organizational Competencies for Change. Economics and Business, 22, 107-111.

17. Liu, D. (2015). Research on fuzzy theory-based government promotion to public sports service development. Open Cybernetics and Systemics Journal, 9, 2295-2300. https://doi. org/10.2174/1874110X01509012295

18. Lucey, T. (2009). Costing (7th ed.). London: BookPower. 
19. Mamdani, E. H., \& Assilian, S. (1975). An Experiment in Linguistic Synthesis with a Fuzzy Logic Controller. International Journal of Man-Machine Studies, 7 (1), 1-13. http://doi:10.1016/ S0020-7373(75)80002-2

20. Micheli, P., \& Luca, M. (2014), Theory and Practice of Performance Management. Management Accounting Research, 25 (2), 147-156. https://doi.org/10.1016/j.mar.2013.07.005

21. Moradi, N., Mousavi, S. M., \& Vahdani, B. (2017). An earned value model with risk analysis for project management under uncertain conditions. Journal of Intelligent and Fuz₹y Systems, 32 (1), 97-113. https://doi.org/10.3233/JIFS-151139

22. Nishimura, A. (2019). Management, Uncertainty, and Accounting. Singapore: Palgrave Macmillan. https://doi.org/10.1007/978-981-10-8989-3

23. Novák, P., \& Popesko, B. (2014). Cost Variability and Cost Behaviour in Manufacturing Enterprises. Economics and Sociology, 7(4), 89-103. doi:dx.doi.org/10.14254/2071789X.2014/7-4/6

24. Otley, D. (2016). The Contingency Theory of Management Accounting and Control: 1980-2014. Management Accounting Research, 31, June, 45-62. https://doi.org/10.1016/ j.mar.2016.02.001

25. Otley, D., \& Pollanen, R. (2000). Budgetary Criteria in Performance Evaluation: A Critical Appraisal Using New Evidence. Accounting, Organizations and Society, 25 (4-5), 483-496. https://doi.org/10.1016/S0361-3682(98)00031-2

26. Otley, D., \& Soin, K. (2014). Management Control and Uncertainty. London: Palgrave Macmillan. https://doi.org/10.1057/9781137392121

27. Papazov, E., \& Mihaylova, L. (2014). Linking Accounting Information with Business Planning in Bulgarian SMEs. In: Proceedings of 8th IMC: Management challenges for sustainable development, Bucharest, Romania, 321-327.

28. Sousa, S., Lopes, I., \& Nunes, E. (2015). Graph Theory Approach to Quantify Uncertainty of Performance Measures. International Journal for Quality Research, 9 (1), 37-50.

29. Todorova, D. (2012). Competitiveness and sustainable development of ground transport. Ikonomicheski iæsledvania, 21 (3), 68-77.

30. Todorova, D., \& Marinova, D. (2018). Problems of the Staff Education Process in Bulgarian Companies. Mechanics Transport Communications, 16 (1), 1-6.

31. Tuček, D. (2015). The Main Reasons for Implementing BPM in Czech Companies. Journal of Competitiveness, 7 (3), 126-142. https://doi.org/doi.org/10.7441/joc.2015.03.09

32. Williams, R. (1998). Performance management: Perspectives on employee performance. UK: International Thomson Business Press.

33. Yiu, C., Ho, H., Lo, S., \& Hu, B. (2005). Performance Evaluation for Cost Estimators by Reliability Interval Method. ASCE Journal of Construction Engineering and Management, 131 (1), 108-116.

34. Zhang, X. (2014). Management Control Elements and Management Control Systems. In: Enterprise Management Control Systems in China. Understanding China. Berlin: Springer. https:// doi.org/10.1007/978-3-642-54715-7_8 


\section{Contact information}

prof. Ing. Maya Lambovska, DSc.,

University of National and World Economy in Sofia

Faculty of Management and Administration

E-mail:mlambovska@abv.bg

ORCID: 0000-0003-3285-3051

doc. Ing. Rastislav Rajnoha, PhD.

Tomas Bata University in Zlin

Faculty of Management and Economics

E-mail:rajnoha@fame.utb.c\%.

ORCID: 0000-0002-9332-9926

doc. Ing. Jan Dobrovic, PhD.

University of Prešov in Prešov

Faculty of Management

E-mail:jan.dobrovic@unipo.sk

ORCID: 0000-0002-0637-106X 